\title{
PENGARUH PENAMBAHAN AIR LAUT TERHADAP PERUBAHAN ARUS LISTRIK DAN pH PADA PENGOLAHAN AIR LIMBAH INDUSTRI SECARA ELEKTROKOAGULASI
}

\author{
Sutanto $^{1{ }^{\otimes}}$ dan Rahmat ${ }^{2}$ \\ 1,2Program Studi Telekomunikasi, Jurusan Teknik Elektro, Politeknik Negeri Jakarta, Jl. Prof. Dr. G.A. \\ Siwabessy, Kampus UI, Depok \\ $\square_{e-m a i l: ~ s u t a n t o @ e l e k t r o . p n j . a c . i d}$
}

\begin{abstract}
Electronic industrial wastewater is the main raw material for processing into clean water. The electrocoagulation process is one of the methods used to treat wastewater into clean water. The process is carried out in a tank that is divided into three cell that have been installed with a DC voltage source, anode and cathode made of aluminum. In the initial study, 1.5 liters of wastewater which had not been added to the sea water was used in each cell. The electrocoagulation process was run at a voltage of 12 $V$ with 5 minute intervals to observe changes in electric current and $\mathrm{pH}$. Subsequently, the same procedure was performed and added the sea water with variation of volume of 2,4 and 6 mL The best research results are shown in the use of $4 \mathrm{~mL}$ seawater, voltage of $12 \mathrm{~V}$ and processing time of 40 minutes. From this best condition, it is found that the electric current can be increased from 0.11 A to $1.13 \mathrm{~A}$ or about 10.3 times the initial current, while the pH has increased from 7.25 to 8.45 or about $16.55 \%$.
\end{abstract}

Keywords: wastewater, electrocoagulation, sea water, electric current, $\mathrm{pH}$

\begin{abstract}
Abstrak
Air limbah industri elektronika merupakan bahan baku utama yang diproses menjadi air bersih. Proses elektrokoagulasi merupakan salah satu metode yang digunakan untuk mengolah air limbah tersebut menjadi air bersih. Proses dijalankan dalam bak yang terbagi dalam tiga sel yang dilengkapi sumber tegangan DC, anoda dan katoda dari bahan aluminium. Pada penelitian awal digunakan air limbah 1,5 liter yang belum ditambah air laut, dimasukkan ke dalam masing-masing sel. Proses elektrokoagulasi dijalankan pada tegangan $12 \mathrm{~V}$ dengan interval waktu 5 menit untuk mengamati perubahan arus listrik dan pH. Pada penelitian berikutnya dijalankan seperti langkah awal, akan tetapi pada setiap proses elektrokoagulasi ditambahkan air laut dengan perubahan volume masing-masing 2 , 4 dan $6 \mathrm{~mL}$. Perubahan arus listrik diukur dengan amperemeter dan $\mathrm{pH}$ menggunakan pH meter. Hasil penelitian terbaik ditunjukkan untuk pemakaian air laut $4 \mathrm{~mL}$, tegangan $12 \mathrm{~V}$ dan waktu proses 40 menit. Dari keadaan terbaik tersebut, didapatkan bahwa arus listrik dapat ditingkatkan dari dari 0,11 A menjadi 1,13 A atau sekitar 10,3 kali dari arus awal, sedangkan pH mengalami peningkatan dari 7,25 menjadi 8,45 atau sekitar $16,55 \%$.
\end{abstract}

Kata kunci: air limbah, air laut, elektrokoagulasi, arus listrik, $\mathrm{pH}$

\section{Pendahuluan}

Air limbah industri atau rumah tangga sangat berpotensi untuk diolah kembali menjadi air bersih atau air minum. Jika air limbah tersebut akan diolah kembali menjadi air minum, maka kandungan maksimum parameter air hasil pengolahan tersebut harus mengikuti perturan Menteri Kesehatan Kesehatan RI No 492 / Menkes / Per / IV / 2010. Peraturan Menteri Kesehatan tersebut telah menjelaskan bahwa kandungan maksimum untuk tingkat kejernihan air adalah 5 NTU dan tingkat keasaman adalah atau $\mathrm{pH}$ 6,5 - 8,5. 
Metode yang dapat digunakan untuk memanfaatkan kembali air bekas atau limbah menjadi air minum. Salah satu yang digunakan adalah proses elektrokoagulasi. Untuk menjalankan proses tersebut dibutuhkan anoda yang dapat menghasilkan senyawa koagulan. Pada umumnya anoda yang digunakan adalah aluminium atau besi. Senyawa koagulan berfungsi untuk mengadsorpsi berbagai bahan pencemar yang terkandung dalam air limbah.

Secara umum bahan pencemar yang terdapat dalam air limbah sangat beragam, maka daya hantar listrik air limbah pada umumnya sangat rendah. Sehingga untuk menjalankan proses tersebut dibutuhkan tegangan listrik yang cukup tinggi, supaya arus yang dapat dialirkan juga menjadi cukup tinggi. Arus dapat ditingkatkan dengan menambahkan larutan elektrolit ke dalam air limbah. Beberapa contoh larutan yang dapat ditambahkan antara lain: larutan $\mathrm{Ca}(\mathrm{NO})_{3}, \mathrm{NaCl}$, larutan $\mathrm{Na}_{2} \mathrm{SO}_{4}$, larutan $\mathrm{NaI}$, larutan $\mathrm{NaBr}$ dan larutan $\mathrm{Na}_{2} \mathrm{PO}_{4}$. Jika arus yang mengalir cukup tinggi, maka proses elektrokoagulasi dapat berjalan lebih lancar dan proses pengolahana air limbah menjadi lebih cepat [1].

Air yang mengandung garam dapat berfungsi sebagai penghantar arus listrik sedikit dibawah penghantar dari kabel tembaga. Hasil penelitian menunjukkan bahwa 400 gram garam dapur $(\mathrm{NaCl})$ yang dilarutkan dalam 1 liter air mampu mengalirkan arus listrik rata-rata 0,3 A, sedangkan pada tegangan yang sama kabel tembaga mampu mengalirkan arus listrik rata-rata 0,4 A. Artinya larutan garam dapur mampu mengalirkan arus listrik sekitar $75 \%$ dari kemampuan penghantaran listrik oleh kabel tembaga [2].

Salah satu hasil penelitian pada proses elektrokoagulasi air limbah dengan elektroda aluminium yang ditambahkan bahan elektrolit $\mathrm{Na}_{2} \mathrm{SO}_{4} \quad$ (Natrium Sulfat) ternyata mampu meningkatkan konduktivitas larutan atau arus listrik, sehingga dapat mempercepat proses pembentukan koagulan $\mathrm{Al}(\mathrm{OH})_{3}$ yang berperan sebagai bahan adsorben polutan. Selama proses elektrokoagulasi tersebut terjadi pula pembentukan hasil samping berupa senyawa khlorin organik yang bersifat disinfektan (membunuh bakteri) [3]. Berdasarkan hasil peneltian tersebut diperoleh efisiensi penghilangan bakteri Escherichia Koli antara 94,87 \% sampai 95,64\%. Persamaan efisiensi yang digunakan untuk mehitung jumlah bakteri yang hilang dituliskan sebagai berikut:

$\mathrm{E}=[\mathrm{No}-\mathrm{Nt}] / \mathrm{No} \mathrm{x} 100 \%$

dengan: $\mathrm{E}=$ efisiensi penghilangan bakteri (\%), No = jumlah bakteri awal(CFU/ Colony-Forming Units per $\mathrm{mL}), \mathrm{Nt}=$ jumlah bakteri setelah prsoses sterilisasi (CFU/ Colony-Forming Units per $\mathrm{mL})$.

Penelitian proses elektrokoagulasi dengan menggunakan aluminium sebagai elektroda yang dijalankan dengan penambahan garam dapur $(\mathrm{NaCl})$ terbukti dapat menurunkan kandungan algae (ganggang) dalam air. Efisiensi hasil penelitian tersebut dapat mencapai diatas $90 \% \%$ [4].

Hasil penelitian lain menunjukkan bahwa penambahan $\mathrm{NaCl}$ pada proses elektrokoagulasi mampu menurunkan kandungan khrom $(\mathrm{Cr})$ dalam air dari $0,8221 \mathrm{ppm}$ menjadi $0,6128 \mathrm{ppm}$ atau sekitar $25,46 \%$

Penelitian lain menunjukkan bahwa pada proses elektrokoagulasi yang ditambah $\mathrm{NaCl} 740$ mg/L dapat mengurangi "chemical oxygen demand "(COD) dan "total suspended solid" (TSS) lebih dari $90 \%$. Dalam hal ini garam dapur selain berfungsi sebagai media elektrolit juga berperan sebagai bahan disinfektan. Karena selama proses elektrokoagulasi 
terbentuk senyawa hipokhlorit $\left(\mathrm{OCl}^{-}\right)$ yang bersifat oksidator (disinfektan) dan dapat membunuh bakteri. Mekanisme terbentuknya senyawa hipokhlorit dapat dijelaskan dengan persamaan reaksi berikut [5]:

$$
\begin{aligned}
& \mathrm{NaCl} \rightarrow \mathrm{Na}^{+}+\mathrm{Cl}^{-} \\
& 2 \mathrm{Cl}^{-} \rightarrow \mathrm{Cl}_{2}+2 \mathrm{e} \\
& \mathrm{Cl}_{2}+\mathrm{H}_{2} \mathrm{O} \rightarrow \mathrm{HOCl}+\mathrm{Cl}^{-}+\mathrm{H}^{+} \\
& \mathrm{HOCl} \rightarrow \mathrm{OCl}^{-}+\mathrm{H}^{+}
\end{aligned}
$$

Pengukuran kandungan bakteri yang hidup dalam air dapat dikerjakan menggunakan metode standar atau viable plate count. Sedangkan pengukuran kandungan bakteri yang masih hidup atau sudah mati dapat menggunakan metode spectrophotometer. Dengan demikian dapat dikatakan bahwa metode spectrophotometer digunakan untuk menghitung total bakteri yang ada dalam air [6].

Penelitian proses elektrokoagulasi untuk penanganan polutan yang terkandung dalam air limbah rumah tangga mampu menghilangkan kadar padatan total (TS),Chemical Oxygen Demand (COD) dan bakteri Koliform lebih dari $90 \%$ [7].

Salah satu metode yang pernah dilakukan untuk menurunkan kandungan Cadmium (Cd) dalam limbah cair adalah menggunakan proses elektrokoagulasi. Berdasarkan hasil penelitian ternyata efisiensi penghilangan Cadmium dapat mencapai $100 \%$ dengan waktu proses 5 menit dan daya $1.6 \mathrm{~kW} \mathrm{~h}$ per $\mathrm{m}^{3}[8]$.

Jika proses elektrokoagulasi dijalankan menggunakan aluminium sebagai elektroda maka reaksi yang terjadi dapat dijelaskan sebagai berikut [9]:

reaksi pada anoda (oksidasi):

$$
\mathrm{Al}_{(\mathrm{s})} \rightarrow \mathrm{Al}^{+3}(\mathrm{aq})+3 \mathrm{e}^{-}
$$

reaksi pada katoda (reduksi):

$3 \mathrm{H}_{2} \mathrm{O}_{(\mathrm{l})}+3 \mathrm{e}^{-} \rightarrow 3 \mathrm{OH}^{-}{ }_{(\mathrm{aq})}+3 / 2 \mathrm{H}_{2(\mathrm{~g})}(7)$
Reaksi akhir pada kondisi asam:

$\mathrm{Al}^{+3}{ }_{(\mathrm{aq})}+3 \mathrm{H}_{2} \mathrm{O}_{(\mathrm{l})} \rightarrow 2 \mathrm{Al}(\mathrm{OH})_{3(\mathrm{~s})}+3 \mathrm{H}^{+}{ }_{(\mathrm{aq}}(8)$

Reakasi akhir pada kondisi basa:

$\mathrm{Al}^{+3}{ }_{(\mathrm{aq})}+3 \mathrm{OH}^{-}(\mathrm{aq}) \rightarrow \mathrm{Al}(\mathrm{OH})_{3(\mathrm{~s})}$

Berdasarkan Pers.(8) bila kondisi lingkungan adalah asam, maka dapat dijelaskan bahwa selama proses elektrokoagulasi berlangsung dapat dihasilkan senyawa koagulan $\mathrm{Al}(\mathrm{OH})_{3}$ yang berbentuk gumpalan atau flok dan ion $\mathrm{H}^{+}$. Sedangkan bila kondisi lingkungan adalah basa, maka berdasarkan Per. (9) hanya akan dihasilkan senyawa koagulan $\mathrm{Al}(\mathrm{OH})_{3}$. Fungsi dari senyawa koagulan $\mathrm{Al}(\mathrm{OH})_{3}$ adalah sebagai bahan adsopsi polutan dalam air yang mudah diendapkan pada dasar bak proses. Salah satu kelebihan penggunaan proses elektrokoagulasi adalah tidak diperlukan filter untuk penyaringan bakteri, karena bakteri akan terbawa bersama polutan lain yang telah teradsorpsi oleh bahan koagulan $\mathrm{Al}(\mathrm{OH})_{3}$ dan akan terendapkan ke dasar bak proses.

Alternatif lain untuk membunuh atau menghilangkan bakteri atau mikroorganisme lainnya yang terkandung dalam air limbah dapat dilakukan dengan menambahkan air laut kedalam air limbah yang sedang diproses secara elektrokoagulasi. Karena kandungan dalam air laut terdiri atas garam klorida sebanyak 55\%, garam natrium sebanyak $31 \%$, garam sulfat sebanyak $8 \%$, garam magnesium sebanyak 4\%, garam, garam potasium sebanyak $1 \%$ dan sisanya kurang dari $1 \%$ yang terdiri atas garam bikarbonat, bromida, asam borak, stronsium, dan florida [10]. Berdasarkan kandungan garam khlorida yang mencapai sekitar 55 $\%$ sangat mungkin air laut dapat dijadikan bahan disinfektan atau pensteril air limbah, karena akan terbentuk dipadu dengan proses elektrokoagulasi.Senyawa hipokhlorit 
(OCl) akan berperan sebagai bahan pembunuh atau mengoksidasi mikroorganisme (bakteri atau virus). Pengaruh kondisi asam yang kuat pada proses elektrokoagulasi dapat meningkatkan klorin $\left(\mathrm{Cl}_{2}\right)$ menjadi oksidator yang lebih kuat dibandingkan dengan $\mathrm{HClO}$. Berdasarkan uraian ini dapat dijelaskan bahwa pada harga $\mathrm{pH}$ yang semakin tinggi, maka secara teoritis dapat meningkatkan kemampuan oksidasi elektrokimia dari $\mathrm{HClO}$ dan $\mathrm{ClO}^{-}$[11]. Persamaan reaksi evolusi klorin pada proses oksidasi tidak langsung yang dipengaruhi oleh $\mathrm{pH}$ :

$$
\begin{gathered}
\mathrm{Cl} \rightarrow 1 / 2 \mathrm{Cl}_{2}+\mathrm{e}^{-} \\
\mathrm{Cl}_{2}+\mathrm{H} 2 \mathrm{O} \rightarrow \mathrm{HOCl}+\mathrm{H}^{+}+\mathrm{Cl}^{-} \\
\mathrm{HOCl} \rightarrow \mathrm{ClO}^{-}+\mathrm{H}^{+}
\end{gathered}
$$

Peningkatan konsentrasi $\mathrm{Cl}^{-}$dapat meningkatkan penyisihan atau menurunkan kandunagn polutan, akan tetapi terjadi juga peningkatan pembentukan senyawa organik terklorinasi yang cukup beracun. Jika penggunaan konsentrasi elektrolit semakin pekat maka akan terjadi peningkatan daya hantar listrik. Dengan demikian dapat dijelaskan bahwa proses oksidasi elektrokimia akan lebih ekonomis atau murah apabila dalam air limbah yang diolah mempunyai tingkat salinitas yang tinggi.

Pada penelitian proses elektrokoagulasi untuk pengolahan air limbah rumah, dapat ditunjukkan bahwa proses dapat menghilangkan kadar padatan total (TS) sampai, Chemical Oxygen Demand (COD) dan bakteri Koliform lebih dari 90\%. Proses elektokoagulasi dijalankan dengan menggunakan elektroda stailess steel [12].

Proses elektrokoagulasi juga telah diteliti sebanyak 80 kali, untuk menurunkan kandungan arsen dan florida dalam air dengan kemampuan penurunan atau efisiensi penghilangan mencapai lebih dari $80 \%$. Faktor-faktor yang mempengaruhi antara lain jenis elektroda, rapat arus listrik, penambahan elektrolit dan pH lingkungan [13].

Kelengkapan untuk proses elektrokoagulasi yang dibutuhkan antara lain bak proses, sumber DC (arus searah), anoda dan katoda. Bak proses harus bersifat isolator yang dibuat dari bahan akrilik, beton, kaca atau baja yang berlapis bahan isolator. Anoda dapat dibuat dari bahan aluminium atau besi. Sedangkan katoda dapat dibuat dari bahan inert (misal karbon), aluminium atau besi [14].

\section{Metode Penelitian}

Langkah yang telah dilakukan dalam penelitian ini terdiri atas penyiapan bahan dan alat serta prosedur kerja. Bahan yang dipakai adalah aluminium jenis HTC 16-35 sebagai elektroda, air laut dan air limbah industri elektronika. Sedangkan untuk alat menggunakan antara lain bak proses, sumber tegangan arus searah (DC), ampermeter, flow meter, dan $\mathrm{pH}$ meter.

\section{Prosedur}

Prosedur atau tata urutan penelitian dilakukan sebagai berikut: mengukur kandungan polutan dalam air limbah industri elektronika, mengintalasi alat penelitian dan pelaksanaan penelitian

\section{Mengukur kandungan kimiawi air limbah industri elektronika}

Kandungan kimiawi dalam air limbah yang diukur antara lain: konsentrasi logam, minyak dan lemak. Konsentrasi logam diukur dengan AAS, sedangkan minyak dan lemak menggunakan Soxhlet. Kuantitas lain yang diukur adalah kekeruhan dan $\mathrm{pH}$. Dalam hal ini $\mathrm{pH}$ diukur menggunakan $\mathrm{pH}$ meter, sedangkan kekeruhan dengan 
turbidimeter. Hasil pengukuran parameter ditunjukkan dalam Tabel 1 .

Tabel 1. Hasil pengukuran parameter air limbah

\begin{tabular}{lc}
\hline Parameter & Hasil Pengukuran \\
\hline Besi $(\mathrm{Fe})$ & $1,42 \mathrm{mg} / \mathrm{L}$ \\
Tembaga $(\mathrm{Cu})$ & $4,32 \mathrm{mg} / \mathrm{L}$ \\
Aluminium $(\mathrm{Al})$ & $0,75 \mathrm{mg} / \mathrm{L}$ \\
Kekeruhan & $43,56 \mathrm{NTU}$ \\
pH & 7,25 \\
\hline
\end{tabular}

\section{Merangkai alat penelitian}

Model dari peralatan penelitian dapat ditunjukkan seperti Gambar 1. Susunan alat proses tersusun atas sumber tegangan DC, avometer, tangki air limbah, tangki air laut, bejana elektrokoagulasi, tangki pengendap polutan dan bak penampung air bersih.

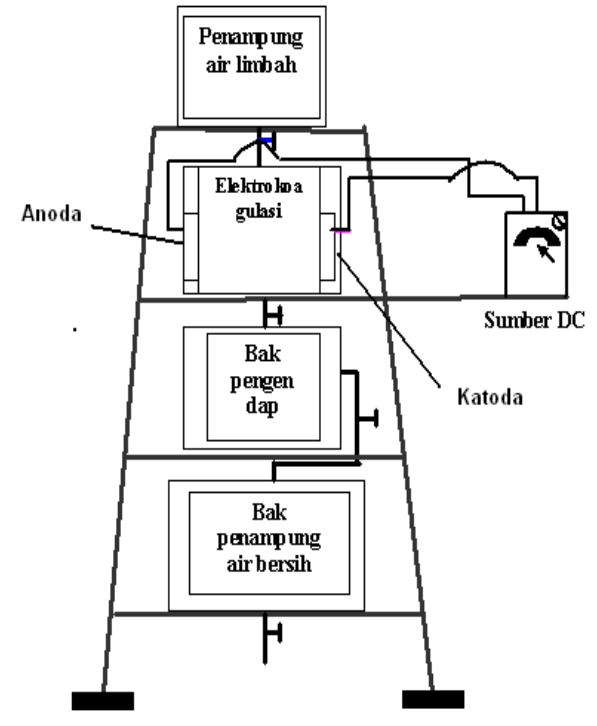

Gambar 1. Model peralatan penelitian

\section{Pelaksanaan Penelitian}

Penelitian awal dijalankan dengan melakukan proses elektrokoagulasi air buangan dari limbah indstri 4,5 liter tanpa penambahan air laut. Air limbah terbagi secara merata kedalam tiga sel elektrokoagulasi, masing - masing sel dimasukkan 1,5 liter air limbah. Selanjutnya menghidupkan sumber DC pada tegangan $12 \mathrm{~V}$. Perubahan arus listrik dan harga $\mathrm{pH}$ diamati pada setiap interval waktu 5 menit. Pengukuran arus listrik menggunakan amper meter dan $\mathrm{pH}$ menggunakan $\mathrm{pH}$ meter. Proses elektrokoagulasi dihentikan setelah waktu proses berlangsung 50 menit. Pada penelitian selanjutnya langkah yang dilakukan sama seperti pada langkah awal, akan tetapi air limbah pada setiap sel ditambahkan air laut dengan volume yang divariasikan, yaitu 2, 4 dan $6 \mathrm{~mL}$.

\section{Hasil dan Pembahasan}

Hasil penelitian akan dibahas menjadi dua bagian, yaitu bahasan yang terkait dengan variasi tambahan air laut terhadap perubahan arus listrik dan $\mathrm{pH}$ dengan mempertimbangkan kondisi optimum untuk membuat air bersih atau air minum.

Pengaruh variasi volume tambahan air laut terhadap perubahan arus listrik

Hasil pengukuran perubahan arus listrik dari proses elektrokogulasi air limbah yang ditambah air laut dengan variasi 2 , 4 dan $6 \mathrm{~mL}$ ditunjukkan pada Tabel 2. Hasil uji statistik dari data Tabel 2 dengan model distribusi t untuk taraf nyata $1 \%$, menunjukkan bahwa arus rata-rata 0,11 A dapat diterima pada proses elektrokoagulasi yang dijalankan tanpa penambahan air laut. Sedangkan arus rata-rata $0,42 \mathrm{~A}$ juga dapat diterima untuk proses elektrokoagulasi dengan penambahan air laut $2 \mathrm{~mL}$. Demikian pula arus rata-rata 1,13 A dapat diterima untuk proses elektrokoagulasi dengan penambahan air laut $4 \mathrm{~mL}$ dan arus ratarata 2,14 A dapat diterima juga untuk proses elektrokoagulasi dengan penambahan air laut $6 \mathrm{~mL}$. 
Tabel 2. Hasil pengukuran arus listrik (A)

\begin{tabular}{lllll}
\hline Waktu & \multicolumn{4}{c}{ Penambahan air laut } \\
(menit) & $0 \mathrm{~mL}$ & $2 \mathrm{~mL}$ & $4 \mathrm{~mL}$ & $6 \mathrm{~mL}$ \\
& & & & \\
\hline 0 & 0,10 & 0,41 & 1,12 & 2,16 \\
5 & 0,11 & 0,42 & 1,12 & 2,15 \\
10 & 0,12 & 0,42 & 1,13 & 2,14 \\
15 & 0,12 & 0,43 & 1,13 & 2,15 \\
20 & 0,10 & 0,42 & 1,12 & 2,13 \\
25 & 0,11 & 0,41 & 1,13 & 2,14 \\
30 & 0,12 & 0,42 & 1,14 & 2,13 \\
35 & 0,11 & 0,41 & 1,12 & 2,14 \\
40 & 0,10 & 0,43 & 1,12 & 2,14 \\
45 & 0,12 & 0,42 & 1,13 & 2,13 \\
50 & 0,11 & 0,44 & 1,12 & 2,14 \\
\hline
\end{tabular}

Hasil pengukuran perubahan arus listrik dari proses elektrokogulasi air limbah yang ditambah air laut dengan variasi 2 , 4 dan $6 \mathrm{~mL}$ dapat juga dilihat pada Gambar 2.

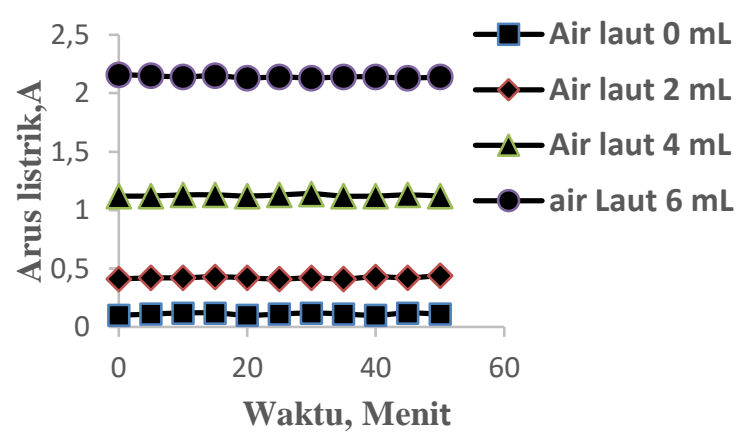

Gambar 2. Kurva hubungan antara waktu terhadap perubahan arus listrik

Berdasarkan Gambar 2 dapat ditunjukkan bahwa pada penambahan air laut dapat meningkatkan arus listrik. Pada penambahan air laut $2 \mathrm{~mL}$ dapat meningkatkan arus listrik rata-rata dari 0,11 A menjadi 0,42 A atau naik 3,8 kali dari arus semula. Sedangkan pada penambahan aiar laut $4 \mathrm{~mL}$ dapat meningkatkan arus listrik rata-rata dari 0,11 A menjadi 1,13 A atau naik 10,3 kali dari arus semula dan pada penambahan air laut $6 \mathrm{~mL}$ dapat meningkatkan arus listrik rata-rata dari
0,11 A menjadi 2,14 A atau naik 19,5 kali dari arus semula. Peningkatan arus listrik terjadi karena terjadi penurunan tahanan jenis larutan pada saat ditambahkan air laut ke dalam air limbah [2], [10].

\section{Pengaruh penambahan air laut terhadap perubahan $\mathrm{pH}$}

Hasil pengukuran perubahan $\mathrm{pH}$ dari proses elektrokogulasi air limbah yang ditambah air laut dengan variasi 2, 4 dan $6 \mathrm{~mL}$ ditampilkan pada Tabel 3. Dari Tabel 3, dapat dijelaskan bahwa pada proses tanpa penambahahan air laut yang dijalankan selama 50 menit terjadi peningkatan $\mathrm{pH}$ dari 7,25 menjadi 8,34 atau setara dengan $15 \%$. Sedangkan proses elektrokoagulasi yang dilakukan selama 50 menit pada air limbah yang ditambahkan air laut $2 \mathrm{~mL}$ terjadi peningkatan $\mathrm{pH}$ dari 7,25 menjadi 8,57 atau setara dengan $18,21 \%$. Demikian juga pada proses elektrokoagulasi yang ditambah air laut $4 \mathrm{~mL}$ dapat meningkatkan harga $\mathrm{pH}$ dari 7,25 menjadi 8,75 atau setara $20,69 \%$ dengan lama proses 50 menit. Terakhir pada proses elektrokagulasi yang ditambah air laut $6 \mathrm{~mL}$ dapat meningkatkan harga $\mathrm{pH}$ dari 7,25 menjadi 9,10 atau setara 25,52 $\%$ dengan lama proses 50 menit. Hal ini terjadi sebagai akibat dari semakin banyaknya $\mathrm{OH}^{-}$yang terbentuk dalam larutan. Sebagaimana diketahui bahwa selama berlangsungnya proses ektrokogulasi padakatoda terbentuk yang $\mathrm{OH}^{-}$yang sangat menentukan sifat kebasaan larutan. Semakin banyak terbentuk ion $\mathrm{OH}^{-}$akan berakibat pada peningkatan $\mathrm{pH}$ air [1], [6], [7],[11]-[14].

Berdasarkan peraturan Menteri Kesehatan Kesehatan RI No 492 / Menkes / Per / IV / 2010 disebutkan bahwa $\mathrm{pH}$ untuk air yang berstandar air 
minum adalah antara 6, 5 s.d 8,5. Dengan mengacu pada tabel 3 dapat dijelaskan bahwa proses elektrokaogulasi dalam waktu 50 menit, yang tidak disertakan penambahan air laut ternyata air hasil proses masih memenuhi syarat sebagai air minum, karena harga $\mathrm{pH}$ berkisar antara 7,25 s.d 8,34 . Artinya harga $\mathrm{pH}$ air hasil proses berada pada kisaran antara 6,5 s.d 8,5 masih sesuai dengan peraturan Menteri Kesehatan Kesehatan RI No 492 / Menkes / Per / IV / 2010.

Tabel 3. Hasil pengukuran $\mathrm{pH}$

\begin{tabular}{ccccc}
\hline Waktu & \multicolumn{4}{c}{ Penambahan air laut } \\
(menit) & $0 \mathrm{~mL}$ & $2 \mathrm{~mL}$ & $4 \mathrm{~mL}$ & $6 \mathrm{~mL}$ \\
\hline 0 & 7,25 & 7,25 & 7,25 & 7,25 \\
5 & 7,26 & 7,28 & 7,32 & 7,45 \\
10 & 7,28 & 7,35 & 7,41 & 7,55 \\
15 & 7,48 & 7,55 & 7,65 & 7,85 \\
20 & 7,61 & 7,65 & 7,85 & 7,98 \\
25 & 7,81 & 7,95 & 8,15 & 8,25 \\
30 & 7,98 & 8,12 & 8,25 & 8,45 \\
35 & 8,11 & 8,24 & 8,35 & 8,65 \\
40 & 8,19 & 8,35 & 8,45 & 8,85 \\
45 & 8,23 & 8,45 & 8,55 & 8,95 \\
50 & 8,34 & 8,57 & 8,75 & 9,10 \\
\hline
\end{tabular}

Untuk proses elektrokaogulasi yang ditambah air laut $2 \mathrm{~mL}$ selama proses berlangsung 45 menit, ternyata air hasil proses masih memenuhi syarat sebagai air minum, karena harga $\mathrm{pH}$ berkisar antara 7,25 s.d 8,45. Untuk proses elektrokaogulasi yang ditambah air laut $4 \mathrm{~mL}$ selama proses berlangsung 40 menit, ternyata air hasil proses masih memenuhi syarat sebagai air minum, karena harga $\mathrm{pH}$ berkisar antara 7,25 s.d 8,45 . Untuk proses elektrokaogulasi yang ditambah air laut $6 \mathrm{~mL}$ selama proses berlangsung 30 menit, ternyata air hasil proses masih memenuhi syarat sebagai air minum, karena harga $\mathrm{pH}$ berkisar antara 7,25 s.d 8,45. Direkomendasikan proses yang terbaik supaya air hasil proses tidak terasa asin, disarankan penambahan air laut dibatasi tertingi $4 \mathrm{~mL}$ dengan waktu proses maksimum 40 menit. Pada kondisi ini arus listrik yang mengalir rata-rata sebesar 2,14 A.

Hasil pengukuran perubahan $\mathrm{pH}$ dari proses elektrokogulasi air limbah yang ditambah air laut dengan variasi 2, 4 dan $6 \mathrm{~mL}$ ditunjukkan juga pada Gambar 3.

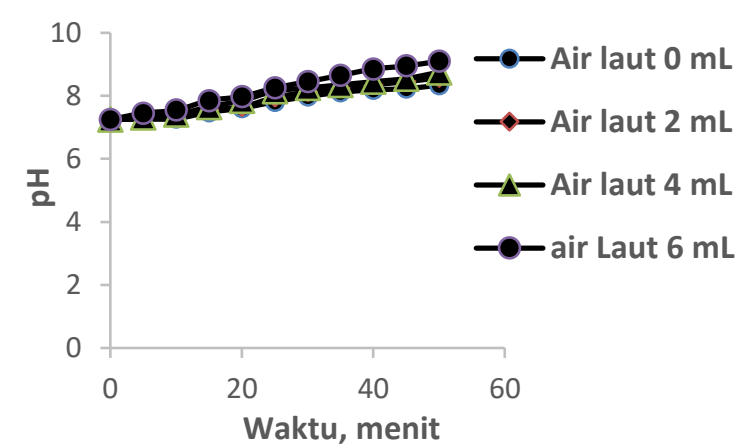

Gambar 3. Kurva hubungan antara waktu terhadap perubahan $\mathrm{pH}$

Berdasarkan Gambar 3 dapat dijelaskan bahwa pada proses elektrokoagulasi yang ditambah air laut $2 \mathrm{~mL}$ menunjukkan bahwa $\mathrm{pH}$ air semakin meningkat. Hal ini disebabkan adanya peningkatan arus listrik yang cukup besar dari 0,11 A menjadi 0,42 A. Sedangkan ketika air limbah ditambah air laut $4 \mathrm{~mL}$ terjadi peningkatan arus listrik yang semakin besar lagi, yaitu dari 0,11 amper menjadi 1,13 A. Demikian juga ketika kedalam air limbah ditambahkan air laut sebanyak $6 \mathrm{~mL}$, maka terjadi peningkatan arus listrik semakin membesar, yaitu dari 0,11 A menjadi 2,14 A. Peningkatan arus listrik berakibat pada kenaikan pembentukan ion $\mathrm{OH}^{-}$yang beperan pada pengendalian perubahan harga $\mathrm{pH}$ air limbah. Sehingga apabila semakin banyak ion $\mathrm{OH}^{-}$yang terbentuk, maka harga $\mathrm{pH}$ semakin membesar pula. Namun demikian penambahan air laut juga harus diperhitungkan jumlahnya, supaya air hasil proses tidak terasa asin dan harga $\mathrm{pH}$ maksimum 8,5. 


\section{Kesimpulan}

Proses elektrokoagulasi yang ditambah dengan air laut dengan volume terbatas dapat meningkatkan arus listrik dan meningkatkan harga $\mathrm{pH}$ air limbah. Kondisi optimum proses elektrokoagulasi untuk menghasilkan air minum adalah tegangan $12 \mathrm{~V}$, waktu proses 40 menit dan penambahan air laut $4 \mathrm{~mL}$. Pada kondisi ini arus listrik dapat ditingkatkan dari 0,11 A menjadi 1,13 A atau terjadi peningktan 10,3 kali dari arus semula, sedangkan harga $\mathrm{pH}$ air dapat ditingkatkan dari 7,25 menjadi 8,45 atau setara dengan $16,55 \%$.

\section{Ucapan Terima Kasih}

Dengan telah terselesaikannya penelitian ini disampaikan banyak terima kasih kepada UP2M yang telah mendukung pendanaan Penelitian Terapan Unggulan Perguruan Timnggi tahun 2020.

\section{Daftar Pustaka}

[1] Aimad, O., dkk. 2020. Treatment of Artificial Pharmaceutical Wastewater Containing Amoxicillin by a Sequential Electrocoagulation with Calcium Salt Followed by Nanofiltration. Journal of Environmental Chemical Engineering, Vol 8, Issue 6.

[2]. Muhammad, H. 2019. Uji Coba Elektroda Pelat Tembaga dan Alumunium Terhadap Air Laut Sebagai Elektrolit Untuk Menghasilkan Energi Listrik Alternatif. Majalah Teknik Simes, Vol 13, No 2.

[3] Longqian, X., dkk. 2017. Simultaneous Removal of Cadmium, Zinc and Manganese using Electrocoagulation: Influence of Operating Parameters and Electrolyte Nature. Journal of Environmental Management, Vol 204, No 1.

[4] Simona, L., dkk. 2021. Electrocoagulation Reduces Harvesting Costs for Microalgae. Bioresource Technology, Vol 323.

[5] Salvador,C.,dkk. 2020.Scaling-up an Integrated ElectrodisinfectionElectrocoagulation Process for Wastewater Reclamation. Chemical Engineering Journal, Vol 380.

[6] Khalid, S., dkk. 2020. Energy Efficient Electrocoagulation using Baffle-Plates Electrodes for Efficient Escherichia coli removal from wastewater. Journal of Water Process Engineering, Vol 33.

[7] Kasem, S., dkk. 2016. Domestic Wastewater Treatment using a Modified Electrocoagulation Process .Mansoura Engineering Journal, Vol 14,Issue 2.

[8] Deepak, S., dkk. 2020. Removal of Chromium (VI) and Lead from Electroplating Effluent using Electrocoagulation Separation Science and Technology, Vol 55, Issue 2.

[9] Seval, Y., dkk. 2018. Treatment of Vinegar Industry Wastewater by Electrocoagulation with Monopolar Aluminum and Iron Electrodes and Toxicity Evaluation. Water Science \&Technology, Vol 78, No 12.

[10] Yusmidiarti, 2019. Pengaruh Air Laut Sebagai Koagulan Air Sumur Gali dalam Penurunan Kekeruhan, Warna, TDS. Jurnal Kesehatan, Vol 12, No 1.

[11] Nandar, S., dkk.2017. Penyisihan Fe,Warna, dan Kekeruhan pada Air Gambut Menggunakan Metode Elektrokoagulasi. Jurnal Teknik Lingkungan, Vol 6, No.2. 
[12] Adegoke, A.T., dkk., 2020. A Preliminary Study on The Treatment of Restaurant Wastewater using Electrocoagulation Technique. Journal of Degraded and Mining Lands Management. Vol 7, Isuue 2.

[13] Miguel, A.S., dkk., 2021. Arsenic and Fluoride Removal by Electrocoagulation Process: A General Review. Science of The Total Environment, Vol 753.

[14] Djamel, G., dkk. 2020.

Electrocoagulation Process in the Context of Disinfection Mechanism. Scientific Research, Vol 7, No 2. 